\title{
Complex Compounds of Sm(III) with Chlorhexidine Synthesis, characterization, luminescent properties and antibacterial activity
}

\begin{abstract}
MIRELA CALINESCU1*, CATALINA STOICA², MIHAI NITA-LAZAR ${ }^{2}$
${ }^{1}$ University of Bucharest, Faculty of Chemistry, Department of Inorganic Chemistry, 23 Dumbrava Rosie Str., 020462, Bucharest, Romania

${ }^{2}$ National Research and Development Institute for Industrial Ecology-ECOIND, $71-72$ Drumul Podu Dambovitei Str., 060652, Bucharest, Romania

Three new samarium(III) complex compounds with chlorhexidine as ligand and mixed ligands chlorhexidine/o-phenanthroline have been prepared and characterized by elemental and thermogravimetrical analyses, infrared, electronic and luminescence spectra. The complexes corresponded to the formulas: $\left[\mathrm{Sm}(\mathrm{CHX})\left(\mathrm{NO}_{3}\right)_{2}\right]^{\prime} \mathrm{NO}_{3^{\prime}}\left[\mathrm{Sm}(\mathrm{CHX})(\mathrm{o} \text {-phen })_{2}\right]^{\prime}\left(\mathrm{NO}_{3}\right)_{3}$ and $\left[\mathrm{Sm}_{2}(\mathrm{CHX})(\mathrm{o} \text {-phen })_{2}\left(\mathrm{NO}_{3}\right)_{4}\right] \times\left(\mathrm{NO}_{3}\right)_{2}$, where $\mathrm{CHX}$ was the chlorhexidine. Chlorhexidine acted as neutral tetradentate NNNN donor, coordinating through the four imine nitrogen atoms. The two mixed ligands complexes showed a strong luminescent emission in solid state, characteristic of samarium(III) ion. The metal complexes and the chlorhexidine diacetate were in vitro evaluated for their antimicrobial activity against two Gram negative bacteria. The results revealed that all compounds were very effective in reducing the bacterial growth rate, even at low concentration.
\end{abstract}

Keywords: Lanthanides, samarium, luminescence, biguanides, chlorhexidine.

Biguanide derivatives are a very important class of drugs, due to their antimalarial, antidiabetic, antimicrobial and antifungal properties [1-4]. The biguanides have a remarkable ability to form chelates with transition metal ions. This interaction is of the greatest importance for coordinative chemistry and many studies have been devoted to this field [5-9].

The most used antimicrobial agent of the biguanide class is chlorhexidine, 1,1'-hexamethylene-bis-[5-( $p$ chlorophenyl)-biguanide] (fig. 1), especially as an active ingredient in mouthwash for plaque and other oral bacteria control [10,11]. Chlorhexidine has been also used in nondental applications, such as general skin and surface cleansing, instrument sterilization and pre-operative skin preparation [12].<smiles>N=C(NCCCCCCNC(=N)NC(=N)Nc1ccc(Cl)cc1)NC(=N)Nc1ccc(Cl)cc1</smiles>

Fig.1. Chlorhexidine $(\mathrm{CHX})$

In recent years, many studies have focused on increasing the effectiveness of chlorhexidine when combined with metal ions. Thus, several studies have demonstrated synergistic inhibitory effect of some metal ions, such as $\mathrm{Zn}^{2+}, \mathrm{Ag}^{+}, \mathrm{Cu}^{2+}$ or $\mathrm{Sn}^{2+}$ with chlorhexidine on various bacteria and fungi [13-16].

In our previous works, we have reported the synthesis and the characterization of some copper(II), zinc(II) and silver(I) complex compounds of chlorhexidine in 1:1 and 2:1 metal: ligand ratio [17-20]. The antimicrobial screening in vitro has shown an increase of activity for most complexes comparatively with chlorhexidine.

The aims of the present study were the synthesis and the characterization of new complex compounds of samarium(III) with chlorhexidine diacetate. It has been known that lanthanide ions coordinate to some biological compounds such as flavonoids [21,22] or vital drugs (metformin) [23]. Literature survey revealed the absence of any reports on the interaction of chlorhexidine with lanthanide ions. Such complexes may be important for their antimicrobial action and also for their possible fluorescent properties. Taking into account these aspects, we reported in this paper the synthesis, characterization, antimicrobial studies and luminescent properties of three complex compounds of samarium(III) with chlorhexidine. In order to improve the luminescent properties, two metal complexes have mixed ligand such as chlorhexidine and o-phenanthroline.

\section{Experimental part}

Materials and physico-chemical analyses

All the chemical used were of reagent grade and were purchased from Sigma-Aldrich and Merck. The metal content was gravimetrically detected, as samarium(III) oxide, $\mathrm{Sm}_{2} \mathrm{O}_{3}$. Carbon, hydrogen and nitrogen were detected using a Euro EA Elemental analyzer. Thermogravimetric analysis was carried out in static air atmosphere, at a heating rate of $10^{\circ} \mathrm{C} / \mathrm{min}$, using a Perkin Elmer STA 6000 derivatograph. Infrared spectra (in $\mathrm{KBr}$ pellets) were recorded on a BIORAD FTIR 135 spectrophotometer, in the range $4000-400 \mathrm{~cm}^{-1}$. UV-Vis diffuse reflectance spectra were registered on a UV-Vis Jasco 650 spectrophotometer, in the range $200-900 \mathrm{~nm}$. Fluorescence measurements were made on a J asco FP 6500 spectrofluorimeter, on solid sample.

\section{Antibacterial analysis}

The in vitro biological effects of the ligand and its $\mathrm{Sm}$ (III) complexes were monitored by the growth inhibition tests on two bacterial species, Escherichia coli (ATCC 25922) and Citrobacter freundii (ATCC 8090), purchased from ATCC. Bacterial grow th medium, lauryl sulphate broth, was purchased from National Research and Development Cantacuzino (Bucharest, Romania). Every bacterial strain 
was initially grown on nutrient agar plates $0 / \mathrm{N}$ at $37^{\circ} \mathrm{C}$, then a single colony was grown in the nutrient broth to a density of 1 OD at an absorbance of $600 \mathrm{~nm}$ (OD600nm). The bacterial growth inhibition test was performed in 96 wells plate in presence or in absence of chemical compounds at various concentrations (ranging from 0 to $50 \mathrm{mM}$ ). Bacterial growing rate was monitored by spectrometry at an absorbance of $600 \mathrm{~nm}\left(A_{6000}\right)$ using Clariostar Microplate Reader (BMG Labtech $\mathrm{GmbH}$ ).

The toxic effect of chemical compounds was quantified in function of bacterial growing rate compared to control samples, no compounds treatment. Each microbiological step had a positive and negative control to ensure quality outcomes and efficiency of working methods.

Sm(III) compounds were solubilized in ethanol, stock solutions of $0.25 \mathrm{M}$.

\section{Synthesis of metal complexes}

[Sm(CHX) $\left.\left(\mathrm{NO}_{3}\right)_{2}\right]^{\prime} \mathrm{NO}_{3}$ (complex 1): $0.6435 \mathrm{~g}(1$ $\mathrm{mmol}$ ) of chlorhexidine diacetate monohydrate were dissolved in $30 \mathrm{~mL}$ ethanol, with stirring. To this solution was added $0.4445 \mathrm{~g}$ ( $1 \mathrm{mmol})$ of $\mathrm{Sm}\left(\mathrm{NO}_{2}\right)_{3} \times 6 \mathrm{H}_{2} \mathrm{O}$ and the resulting solution was stirred at $35-400^{\circ} \mathrm{C}$ for $2^{2} \mathrm{~h}$. The white precipitate obtained was filtered off, washed with ethanol and ether and dried in air. $\mathrm{mp}=216^{\circ} \mathrm{C}$.
[Sm(CHX)(o-phen) ]' $\left(\mathrm{NO}_{3}\right)_{3}$ (complex 2) and $\left[\mathrm{Sm}_{2}(\mathrm{CHX})(\mathrm{o} \text {-phen })_{2}\left(\mathrm{NO}_{3}\right)_{4}\right] \times\left(\mathrm{NO}_{3}\right)_{2}$ (complex 3) were prepared as follows: $0.6435 \mathrm{~g}$ ( $1 \mathrm{mmol}$ ) of chlorhexidine diacetate monohydrate were mixed with $0.3600 \mathrm{~g}$ (2 $\mathrm{mmol}$ ) of o-phenanthroline in $50 \mathrm{~mL}$ ethanol. A solution of $\mathrm{Sm}\left(\mathrm{NO}_{3}\right)_{3} \times 6 \mathrm{H}_{2} \mathrm{O}$ in ethanol $(0.4445 \mathrm{~g}, 1 \mathrm{mmol}$ for the complex 2 and $0.8890 \mathrm{~g}, 2 \mathrm{mmol}$ for the complex 3 ) was added to the mixture of the ligands and the resulting solutions were stirred at $40-50^{\circ} \mathrm{C}$ for $2 \mathrm{~h}$, when solid white products were separated out. These were filtered off, washed with ethanol and ether and dried at air. Complex 2: $\mathrm{mp}=220^{\circ} \mathrm{C}$; complex 3: $\mathrm{mp}=231 \mathrm{C}$ (decomp).

\section{Results and discussions}

The results of the elemental analysis and the proposed formulas based on analytical, thermogravimetrical and IR spectral data were presented in table 1.

All these complexes were partly soluble in acetone, ethanol and acetonitrile, easily soluble in dimethylformamide (DMF) and dimethyl sulfoxide (DMSO). They were quite stable at air, at room temperature and could be stored for several months.

\section{Infrared spectra}

The assignments of the important infrared bands of the chlorhexidine diacetate monohydrate and its samarium(III) complexes were listed in table 2.

\begin{tabular}{|c|c|c|c|c|}
\hline \multirow{2}{*}{ Compound } & \multicolumn{4}{|c|}{ Analysis Found/(Calculated) \% } \\
\cline { 2 - 5 } & $\mathrm{C}$ & $\mathrm{H}$ & $\mathrm{N}$ & $\mathrm{Sm}$ \\
\hline$\left[\mathrm{Sm}(\mathrm{CHX})\left(\mathrm{NO}_{3}\right)_{2}\right] \cdot \mathrm{NO}_{3}$ & 31.04 & 3.60 & 21.40 & 17.61 \\
& $(31.37)$ & $(3.56)$ & $(21.62)$ & $(17.83)$ \\
\hline$\left[\mathrm{Sm}(\mathrm{CHX})(\text { o-phen })_{2}\right] \cdot\left(\mathrm{NO}_{3}\right)_{3}$ & 45.52 & 3.90 & 19.41 & 12.05 \\
& $(45.94)$ & $(3.83)$ & $(19.81)$ & $(12.48)$ \\
\hline$\left[\mathrm{Sm}_{2}(\mathrm{CHX})(\text { o-phen })_{2}\left(\mathrm{NO}_{3}\right)_{4}\right] \cdot\left(\mathrm{NO}_{3}\right)_{2}$ & 35.44 & 3.15 & 18.02 & 19.51 \\
& $(35.91)$ & $(2.99)$ & $(18.21)$ & $(19.51)$ \\
\hline
\end{tabular}

Table 1

ANALYTICAL DATA OF THE METAL COMPLEXES

\begin{tabular}{|c|c|c|c|c|}
\hline Assignments & Chlorhexidine & (1) & (2) & (3) \\
\hline $\mathrm{v}(\mathrm{OH}) \mathrm{H}_{2} \mathrm{O}$ & $\sim 3400 \mathrm{~m}$ & - & - & - \\
\hline $\begin{array}{l}\mathrm{v}(\mathrm{NH}) \text { Alkyl-NH-Aryl } \\
\text { (Alkyl })_{2} \mathrm{NH}\end{array}$ & $3338 \mathrm{~s}$ & $3334 \mathrm{~m}$ & $3335 \mathrm{~m}$ & $3340 \mathrm{~m}$ \\
\hline $\mathrm{v}(=\mathrm{NH})$ & $3181 \mathrm{~s}$ & $3222 \mathrm{~m}$ & $3224 \mathrm{~m}$ & $3220 \mathrm{~m}$ \\
\hline $\begin{array}{l}v_{\mathrm{as}}\left(\mathrm{NH}_{2}^{+}\right) \\
v_{\mathrm{s} g \mathrm{~m}}\left(\mathrm{NH}_{2}^{+}\right)\end{array}$ & $3140 \mathrm{~m}$ & - & - & - \\
\hline $\mathrm{v}(\mathrm{C}=\mathrm{N})$ & $1644 \mathrm{~s}$ & $1635 \mathrm{vs}$ & $1634 \mathrm{~s}$ & $1626 \mathrm{~s}$ \\
\hline $8\left(\mathrm{NH}_{2}^{+}\right)$ & $1613 \mathrm{~m}$ & - & - & - \\
\hline$v_{a s}(\mathrm{COO})$ & $1549 \mathrm{~s}$ & - & - & - \\
\hline$v_{\mathrm{g} z \mathrm{~m}}(\mathrm{COO})$ & $1417 \mathrm{~s}$ & - & - & - \\
\hline$\delta(\mathrm{NH})+v(\mathrm{C}-\mathrm{N})$ & $\begin{array}{l}1574 \mathrm{~s} \\
1337 \mathrm{~m}\end{array}$ & $\begin{array}{l}1580 \mathrm{~m} \\
1349 \mathrm{~m}\end{array}$ & $\begin{array}{l}1579 \mathrm{~m} \\
1350 \mathrm{~m}\end{array}$ & $\begin{array}{l}1590 \mathrm{~m} \\
1348 \mathrm{~m}\end{array}$ \\
\hline
\end{tabular}

Table 2

CHARACTERISTIC BANDS IN THE IR SPECTRA OF CHLORHEXIDINE DIACETATE MONOHYDRATE AND ITS SAMARIUM(III) COMPLEXES $\left(\widetilde{v}_{\max }, \mathrm{cm}^{-1}\right)$ 


\begin{tabular}{|c|c|c|c|c|}
\hline $\mathrm{v}(\mathrm{C}=\mathrm{C})_{\text {arom. }}$ & $\begin{array}{c}1536 \mathrm{vs} \\
1491 \mathrm{~s}\end{array}$ & $\begin{array}{l}1531 \mathrm{vs} \\
1493 \mathrm{~m}\end{array}$ & $\begin{array}{c}1530 \text { vs } \\
1492 \mathrm{~s} \\
1457 \mathrm{~m} \text { (o-phen) } \\
1418 \mathrm{~m} \text { (o-phen) }\end{array}$ & $\begin{array}{c}1540 \mathrm{~s} \\
1485 \mathrm{vs} \\
1425 \mathrm{vs} \text { (o- } \\
\text { phen) }\end{array}$ \\
\hline$v\left(\mathrm{C}_{\text {aliph }}-\mathrm{N}\right)$ & $1249 \mathrm{~m}$ & $1251 \mathrm{~m}$ & $1253 \mathrm{~m}$ & $1257 \mathrm{~m}$ \\
\hline $\mathrm{v}\left(\mathrm{NO}_{3}\right)$ & - & $\begin{array}{c}1383 \mathrm{vs} \\
\left(\mathrm{NO}_{3}{ }^{-} \text {ionic }\right) \\
1020 \mathrm{~m}\left(\mathrm{v}_{2}\right) \\
1348 \mathrm{~m}\left(\mathrm{v}_{1}\right) \\
1568 \mathrm{~m}\left(\mathrm{v}_{5}\right) \\
\left(\mathrm{NO}_{3}{ }^{-} \text {bidentate }\right)\end{array}$ & $\begin{array}{c}1384 \text { vs } \\
\left(\mathrm{NO}_{3}^{-} \text {ionic) }\right.\end{array}$ & $\begin{array}{c}1384 \mathrm{vs} \\
\left(\mathrm{NO}_{3}^{-} \text {ionic) }\right. \\
1030 \mathrm{w}\left(\mathrm{v}_{2}\right) \\
1306 \mathrm{~s}\left(\mathrm{v}_{1}\right) \\
1490 \mathrm{~s}\left(\mathrm{v}_{5}\right) \\
\left(\mathrm{NO}_{3}^{-} \text {bidentate) }\right.\end{array}$ \\
\hline$v(\mathrm{Sm}-\mathrm{O})$ & - & $630 \mathrm{w}$ & - & $639 \mathrm{w}$ \\
\hline$v(\mathrm{Sm}-\mathrm{N})$ & - & $615 \mathrm{w}$ & $620 \mathrm{w}$ & $615 \mathrm{w}$ \\
\hline
\end{tabular}

Table 2

CONTINUATED

The infrared spectrum of chlorhexidine diacetate monohydrate showed manyabsorptions bands in the range of high wave numbers, due to the stretching vibrations $\mathrm{N}$ $\mathrm{H}$ of the groups Alkyl-NH-Aryl and (Alkyl) $\mathrm{NH}$ (at $3338 \mathrm{~cm}$ ${ }^{1}$ ) and to the stretching vibration of the group $=\mathrm{NH}$ (at 3181 $\left.\mathrm{cm}^{-1}\right)[17,19,24]$. Other important bands appearing in the same region were assigned to $v(\mathrm{OH})$ absorption $(\sim 3400$ $\mathrm{cm}^{-1}$ ) and to the symmetric and asymmetric $\mathrm{N}-\mathrm{H}$ stretching modes of $\mathrm{NH}_{2}^{+}$group, at $3140 \mathrm{~cm}^{-1}[17,19,24]$. The presence of this last band was in accordance with the protonation of the chlorhexidine in its diacetate salt, in solid state.

The strong absorption band, at $1644 \mathrm{~cm}^{-1}$, could be assigned to the stretching vibration of the imine function, $n(C=N)[19,25]$. This band was expected to be strongly affected by coordination.

The bands occurring at 1574 and $1337 \mathrm{~cm}^{-1}$ could be attributed to $d(\mathrm{NH})+v(\mathrm{C}-\mathrm{N})$, while the medium absorption band, at $1249 \mathrm{~cm}^{-1}$, was due to $v\left(\mathrm{C}_{\text {a }}-\mathrm{N}\right)$ [26].

The infrared spectrum of the chilorhexidine diacetate also showed bands due to the stretching vibrations of the acetate group: $1549 \mathrm{~cm}^{-1}-v_{\text {as }}$ (COO) and $1417 \mathrm{~cm}^{-1}$ $v_{\text {sum }}(\mathrm{COO})$ [27].

The comparison between the IR absorption bands of the complex compounds and those of chlorhexidine diacetate provided information regarding the nature of groups involved in coordination to the metal ion.

The most obvious change in the IR spectra of the complexes was the shift toward lower wave numbers of the band assigned to $\mathrm{v}(\mathrm{C}=\mathrm{N})$, indicating the coordination of the imine nitrogen atoms to the metal ion $[24,26]$. This hypothesis was also supported by the shift of the bands due to the coupling vibrations $\delta(\mathrm{NH})+v(\mathrm{C}-\mathrm{N})$ and the strong upward shift of the stretching vibrations $v(=\mathrm{NH})$ $[28,29]$.

The band due to the stretching vibrations of $\mathrm{NH}_{2}^{+}$group disappeared in the IR spectra of the complexes, in according to the deprotonation of the chlorhexidine and its involvement in complexation as neutral ligand [28]. Normally, the wave number of $\mathrm{C}=\mathrm{N}$ stretching vibration should increase as a consequence of deprotonation. The negative shift of this band was an indicative of a strong metal-ligand bond.

The very strong band, appearing at $1383-1384 \mathrm{~cm}^{-1}$ in the spectra of all the complexes was due to the stretching vibrations of ionic nitrate [27]. The IR spectra of the complexes (1) and (3) showed also characteristic bands of coordinated nitrate, in the regions $1020-1030 \mathrm{~cm}^{-1}\left(v_{2}\right)$, 1348-1306 $\mathrm{cm}^{-1}\left(v_{1}\right)$ and 1568-1490 $\mathrm{cm}^{-1}\left(v_{5}\right)$ [27]. The separation of two highest frequency bands, $v_{5}-v$ was approximatively $220 / 184 \mathrm{~cm}^{-1}$, in accordance with the participation of the nitrate as bidentate ligand [27].

The IR spectra of the complexes showed supplementary bands at low wave numbers, which could be assigned to $v(\mathrm{Sm}-\mathrm{N})$ and $v(\mathrm{Sm}-0)[27]$.

The free $n(\mathrm{OH})$ band of crystalline water was observed in the IR spectrum of chlorhexidine diacetate monohydrate around $3400 \mathrm{~cm}^{-1}$, but a not corresponding band was observed in the spectra of the metal complexes. The absence of the lattice or coordination water was also confirmed by the thermal analysis of the complexes.

On the base of the IR spectra we can conclude that chlorhexidine acts as neutral tetradentate NNNN donor ligand in all the three complexes, coordinating through the four imine nitrogen atoms. It was also confirmed the presence of ionic nitrate in all the complexes and coordinated nitrate in the complexes (1) and (3).

\section{Thermal analysis}

The results concerning the thermal decomposition of complex compounds were summarized in the table 3.

The complexes were stable up to $200^{\circ} \mathrm{C}$, which was a proof of absence of any crystalline or coordinated water.

The thermal decomposition of the complex (1) undergoes in three steps. The first decomposition step, an exothermic one, in the temperature range of $200-270^{\circ} \mathrm{C}$, with DTG peak at $250^{\circ} \mathrm{C}$, corresponded to ionic nitrate decomposition [30]. The second stage was related to the decomposition of coordinated nitrate and takes place in the temperature range of $290-320^{\circ} \mathrm{C}$, with a maximum rate at $300^{\circ} \mathrm{C}$. The last strong exothermic decomposition step corresponded to the oxidative degradation of chlorhexidine ligand [19]. The mass losses observed for each step were backed up by the calculated values. The final residue of decomposition was $\mathrm{Sm}_{2} \mathrm{O}_{3}$ and the metal percentage 
Table 3

THERMAL DECOMPOSITION DATA FOR Sm(III) COMPLEXES WITH CHLORHEXIDINE

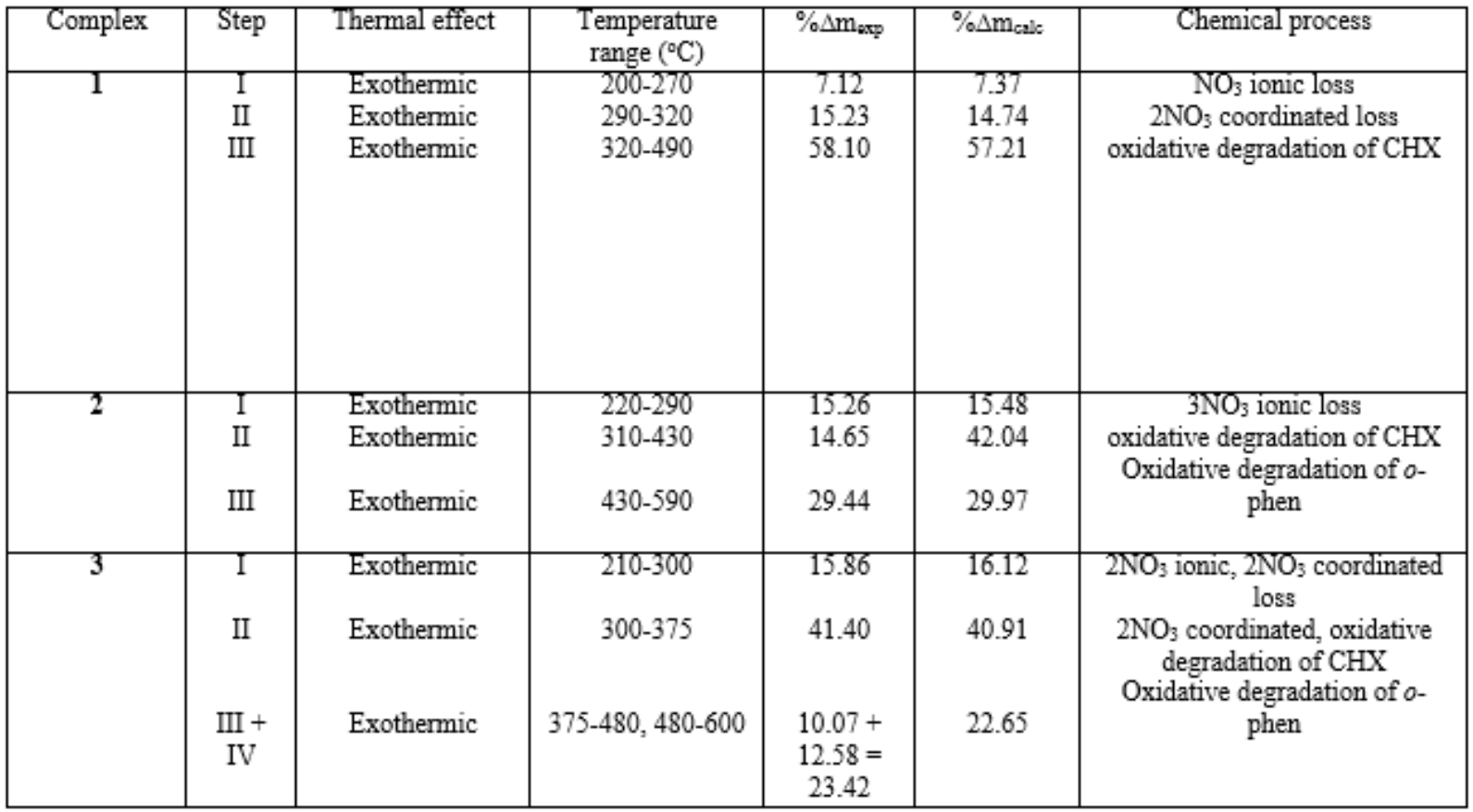

detected from this was in according to the theoretically metal content.

The complex (2) started to decompose at $220^{\circ} \mathrm{C}$, with the decomposition and the loss of ionic nitrate [30]. The next step of thermal decomposition was related to the oxidative degradation of chlorhexidine ligand and undergoes over a temperature range of $310-430^{\circ} \mathrm{C}$, accompanied by a strong exothermic peak. The last step was a complex one and took place at a temperature range of $430-590^{\circ} \mathrm{C}$. According to the literature data, this step can be related to oxidative degradation of $o$-phenanthroline [31].

For the complex (3) the first exothermic stage of thermal decomposition started at $210^{\circ} \mathrm{C}$, with a DTG peak at 254 ${ }^{\circ} \mathrm{C}$ and could be associated with the decomposition and the loss of ionic nitrate and a half of coordinated nitrate. The second step, in the temperature range of $300-375^{\circ} \mathrm{C}$, corresponds to the loss of remaining coordination nitrate and oxidative degradation of $\mathrm{CHX}$. The last decomposition step, consisting in two defined processes, could be associated with the oxidative degradation of 0 phenanthroline [31].

According to the determinations presented above, the following structures have been proposed for the complexes (fig. 2).

\section{Electronic spectral data}

For all the compounds, the electronic spectra were recorded in solid state.

The chlorhexidine diacetate monohydrate exhibited strong absorption bands in the UV region, with peaks at $208 \mathrm{~nm}\left(48100 \mathrm{~cm}^{-1}\right), 255 \mathrm{~nm}\left(39215 \mathrm{~cm}^{-1}\right), 298 \mathrm{~nm}$ $\left(33500 \mathrm{~cm}^{-1}\right)$ and $344 \mathrm{~nm}\left(29000 \mathrm{~cm}^{-1}\right)$, which could be assigned to $n-\sigma^{*}, \pi-\pi *$ and $n-\pi *$ transitions, respectively [17-19].

The UV-Vis spectra of Sm(III) complexes were remarkably different from that of the chlorhexidine ligand. The strong absorption bands in the ultraviolet region, characteristic of the ligand, were slightly shifted to higher or lower energy, as result of the complexation. The shoulders observed in the spectra of the complexes with mixed ligands around $240 \mathrm{~nm}$ were due to the absorption of o-phenanthroline [32]. In addition, the weak absorption bands, in the visible region, may be attributted to $f_{-} f$ transitions of $\mathrm{Sm}^{3+}$ (table 4) [33-35].

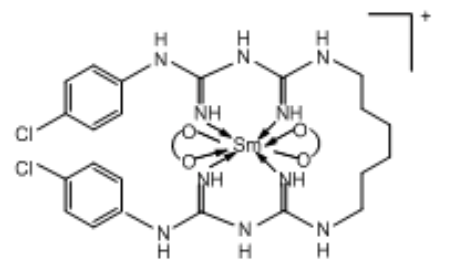

$\left[\mathrm{Sm}(\mathrm{CHX})\left(\mathrm{NO}_{3}\right)_{2}\right] \cdot \mathrm{NO}_{3}$ (complex 1 )

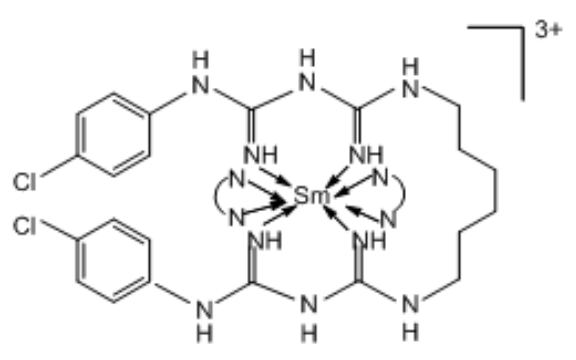<smiles>C1CNCN1</smiles>

o-phen $\left[\mathrm{Sm}(\mathrm{CHX})(\text { o-phen })_{2}\right] \cdot\left(\mathrm{NO}_{3}\right)_{3}$ (complex 2)

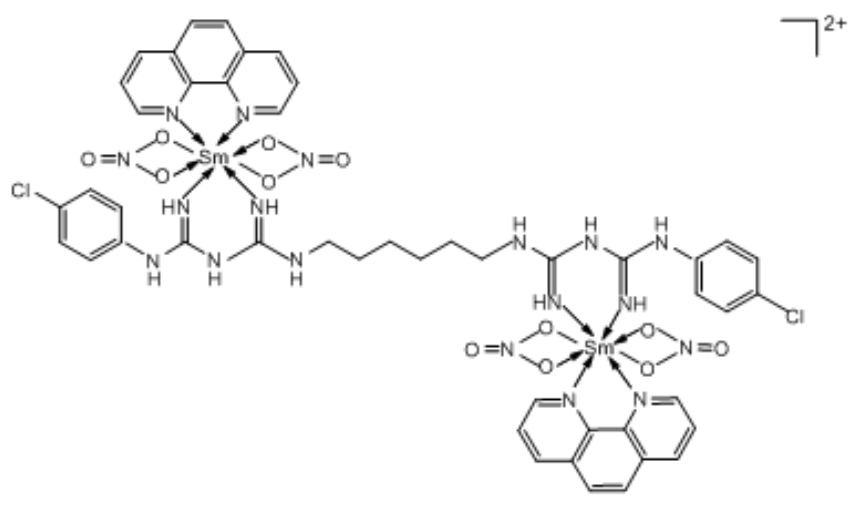

$\left[\mathrm{Sm}_{2}(\mathrm{CHX})(\mathrm{o}-\mathrm{phen})_{2}\left(\mathrm{NO}_{3}\right)_{4}\right] \cdot\left(\mathrm{NO}_{3}\right)_{2}$

Fig. 2. Proposed structures for the Sm(III) complex ions 


\begin{tabular}{|l|c|c|}
\hline \multicolumn{1}{|c|}{ Complex } & Absorptions $\left(\mathrm{cm}^{-1}\right)$ & Assignments \\
\hline$\left[\mathrm{Sm}(\mathrm{CHX})\left(\mathrm{NO}_{3}\right)_{2}\right] \cdot \mathrm{NO}_{3}$ & 16730 & ${ }^{6} \mathrm{H}_{5 / 2} \rightarrow{ }^{4} \mathrm{G}_{5 / 2}$ \\
\hline$\left[\mathrm{Sm}(\mathrm{CHX})(\text { o-phen })_{2}\right] \cdot\left(\mathrm{NO}_{3}\right)_{3}$ & 13600 & ${ }^{6} \mathrm{H}_{5 / 2} \rightarrow{ }^{4} \mathrm{~F}_{1 / 2}$ \\
& 16850 & ${ }^{6} \mathrm{H}_{5 / 2} \rightarrow{ }^{4} \mathrm{G}_{5 / 2}$ \\
& 20450 & ${ }^{6} \mathrm{H}_{5 / 2} \rightarrow{ }^{4} \mathrm{G}_{5 / 2}$ \\
\hline$\left.\left[\mathrm{Sm}_{2}(\mathrm{CHX}) \text { (o-phen }\right)_{2}\left(\mathrm{NO}_{3}\right)_{4}\right] \cdot\left(\mathrm{NO}_{3}\right)_{2}$ & 13500 & ${ }^{6} \mathrm{H}_{5 / 2} \rightarrow{ }^{4} \mathrm{~F}_{1 / 2}$ \\
& 17100 & ${ }^{6} \mathrm{H}_{5 / 2} \rightarrow{ }^{4} \mathrm{G}_{5 / 2}$ \\
& 20830 & ${ }^{6} \mathrm{H}_{5 / 2} \rightarrow{ }^{4} \mathrm{G}_{5 / 2}$ \\
\hline
\end{tabular}

Table 4

VISIBLE ABSORPTION BANDS FOR SAMARIUM(III) COMPLEXES

\section{Luminescence studies}

The emission luminescence spectra were recorded on solid sample; the excitation and the emission slit widths were $5 \mathrm{~nm}$.

The chlorhexidine showed a relative strong and broad emission band, in the range $320-550 \mathrm{~nm}$, with maximum at $390 \mathrm{~nm}$ (excitation at $300 \mathrm{~nm}$ ) (fig. 3).

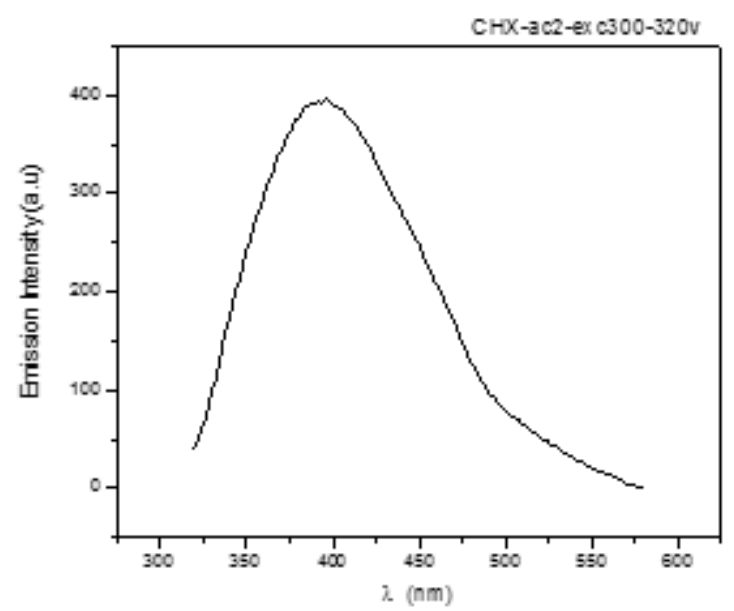

Fig. 3. Emission spectrum of chlorhexidine $\left(\lambda_{\text {exc }}=300 \mathrm{~nm}\right)$

It was known that the emission of $\mathrm{Sm}^{3+}$ complexes consists of three peaks, in the range $550-650 \mathrm{~nm}$, due to the transitions from the resonant ${ }^{4} \mathrm{G}_{5 / 2}$ level to ground levels ${ }^{6} \mathrm{H}_{5 / 2},{ }^{6} \mathrm{H}_{7 / 2}$ and ${ }^{6} \mathrm{H}_{9 / 2}$, respectively [33-37].

The fluorescence spectrum of $\left.\left[\mathrm{Sm}(\mathrm{CHX})\left(\mathrm{NO}_{3}\right)_{2}\right]\right]^{\prime} \mathrm{NO}$ showed a broad emission band, with maximum at 430 $\mathrm{nm}$, which was mainly due to the emission of chlorhexidine ligand. This fact pointed out that the ligand did not very effectively protect the metal from chemical environment, although any water molecule was detected in the first coordination sphere of the metal ion.

The emission of the complex [Sm(CHX)(o-phen) $\left.{ }_{2}\right]^{\prime}$ $\left(\mathrm{NO}_{3}\right)_{3}$ was larger than that of chlorhexidine and it expanded at wavelengths greater than $500 \mathrm{~nm}$, where three clearly-defined weak peaks can be found (fig. 4). They can be attributed to the characteristic transition of $\mathrm{Sm}^{3+}:{ }^{4} \mathrm{G}_{5 / 2} \rightarrow{ }^{6} \mathrm{H}_{5 / 2}(540 \mathrm{~nm}),{ }^{4} \mathrm{G}_{5 / 2} \rightarrow{ }^{6} \mathrm{H}_{7 / 2}(600 \mathrm{~nm})$ and ${ }^{4} \mathrm{G}_{5 / 2} \rightarrow{ }^{6} \mathrm{H}_{9 / 2}(650 \mathrm{~nm})$.

The only compound which shows a typical emission spectrum for $\mathrm{Sm}^{3+}$ ion was $\left[\mathrm{Sm}_{2}(\mathrm{CHX})(0-\right.$ phen) $\left.{ }_{2}\left(\mathrm{NO}_{3}\right)_{4}\right] \times\left(\mathrm{NO}_{3}\right)_{2}$ ( fig. 5).

The three strong and sharp emission bands observed at $565 \mathrm{~nm}, 600 \mathrm{~nm}$ and $648 \mathrm{~nm}$ arise from the transitions:

${ }^{4} \mathrm{G}_{5 / 2} \rightarrow{ }^{6} \mathrm{H}_{5 / 2}{ }^{4} \mathrm{G}_{5 / 2} \rightarrow{ }^{6} \mathrm{H}_{7 / 2}$ and ${ }^{4} \mathrm{G}_{5 / 2} \rightarrow{ }^{6} \mathrm{H}_{9 / 2}$, respectively and any emission from the ligands can be observed in this case. This fact suggests an efficient sensitization process between the ligands and the lanthanide ion, with the ligands acting as an antenna.

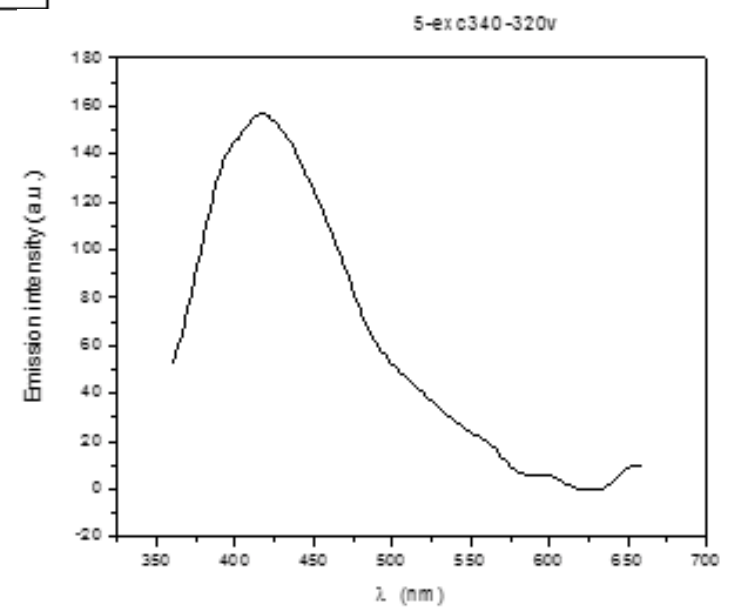

Fig. 4. Emission spectrum of $\left[\mathrm{Sm}(\mathrm{CHX})(\mathrm{o}-\mathrm{phen})_{2}\right]^{\prime}\left(\mathrm{NO}_{3}\right)_{3}$ $\left(\lambda_{\text {exc }}=300 \mathrm{~nm}\right)$

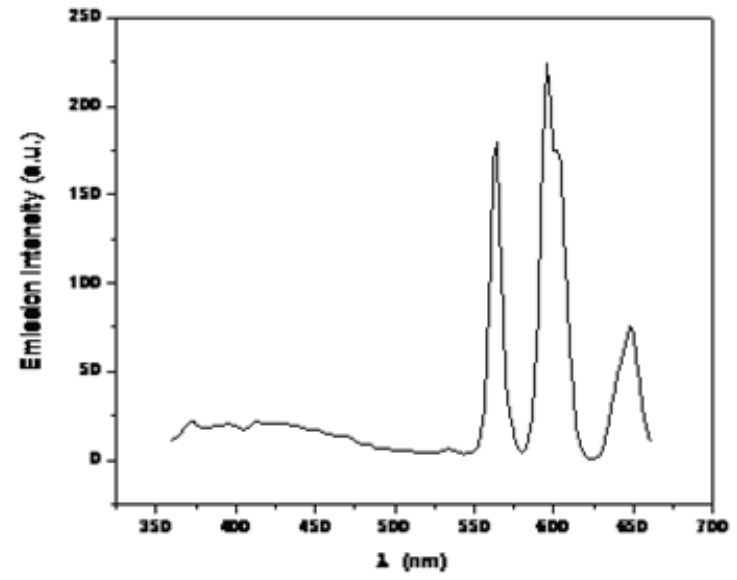

Fig. 5. Emission spectrum of $\left[\mathrm{Sm}_{2}(\mathrm{CHX})(\mathrm{o}-\mathrm{phen})_{2}\left(\mathrm{NO}_{3}\right)_{4}\right] \times\left(\mathrm{NO}_{3}\right)_{2}$ $\left(\lambda_{\text {exc }}=300 \mathrm{~nm}\right)$

\section{Biological activity}

In this study, we analysed the effect of chlorhexidine diacetate and its Sm(III) complexes on two bacterial strains which are naturally present in the environment, $C$. freundii and $E$. coli. The variation of the bacterial growth inhibition over time due to the presence of the complexes or of the chlorhexidine diacetate was shown in figures 6 and 7.

Bacterial growth was monitored by spectrometry at an absorbance at $600 \mathrm{~nm}$ up to $6 \mathrm{~h}$ and the percent of growth inhibition effect of these compounds was compared to the control (bacterial strains without incubation in presence of the compounds).

The results pointed out that these compounds at very low concentrations such as $1 \mathrm{mM}$ and $5 \mathrm{mM}$ were very effective in reducing the bacterial growth rate, for both $C$. freundii and $E$. coli, respectively. The $50 \%$ inhibition rate was attained very 
C. freundii -1-

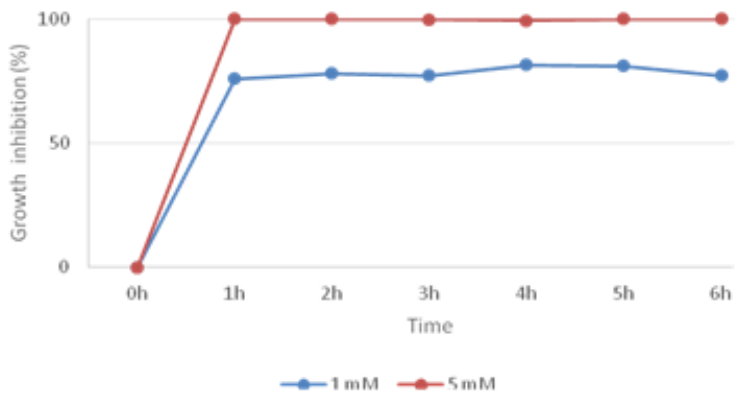

(a)

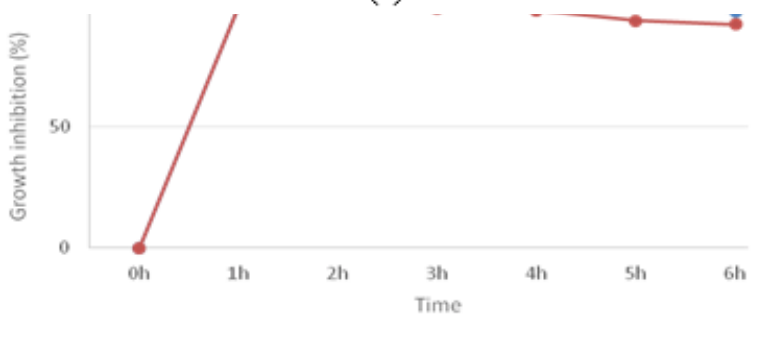

(b)

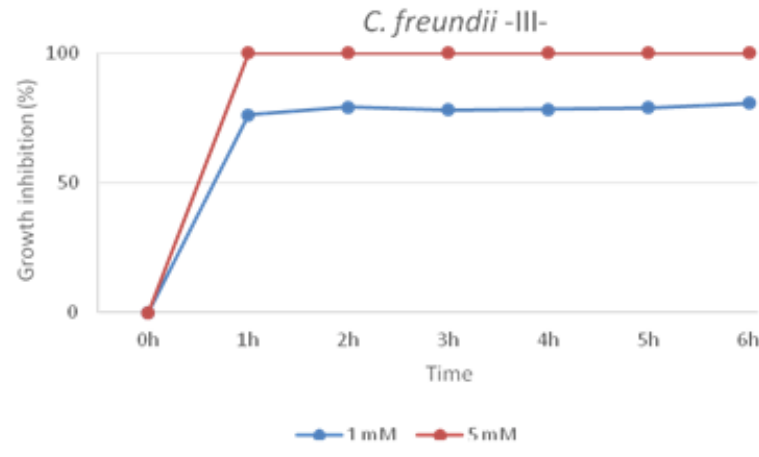

(c)

C. freundii -IV-

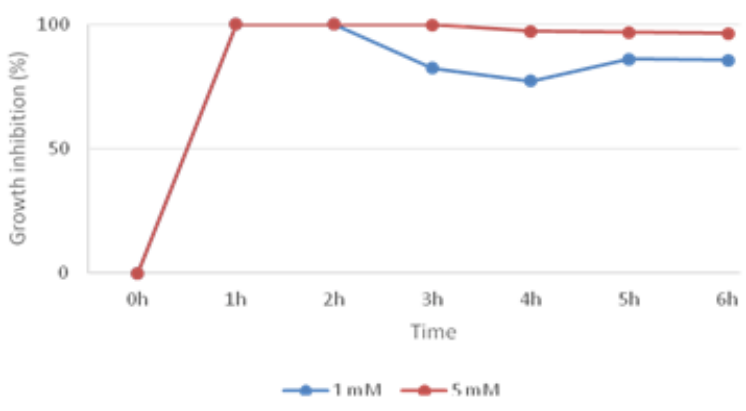

(d)

Fig. 6. Variation of growth inhibition (\%) over time for $C$. freundii in presence of various concentrations of compounds ( $1 \mathrm{mM}$ and

5mM): (a) complex (1); b) complex (2); c) complex (3); d) chlorhexidine diacetate.

fast, after 1 h of bacterial growth, with one exception when $E$. coli was incubated in presence of $1 \mathrm{mM}$ complex (1) for $3 \mathrm{~h}$ to reach $50 \%$ growth inhibition.

Interestingly, E.coli incubated in presence of 1 and $5 \mathrm{mM}$ complex (2) showed, over time, a decrease of the inhibition growth, suggesting a possible defense mechanism such as the efflux pumps [38].

We also tested $50 \mathrm{mM}$ for all the three complexes, but the results were comparable to $5 \mathrm{mM}$, since $5 \mathrm{mM}$ was very effective to inhibit the growth rate.

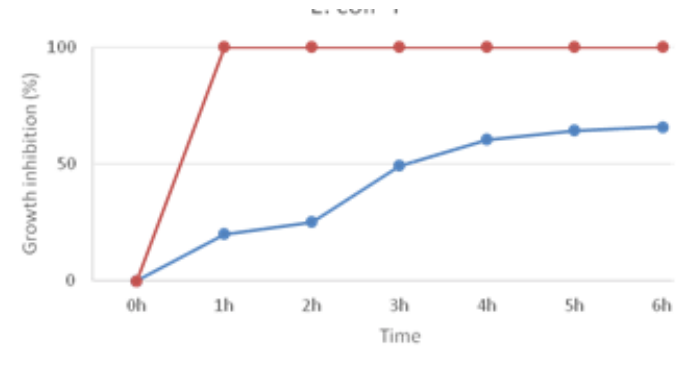

$\rightarrow-1 \mathrm{mM} \rightarrow-5 \mathrm{mM}$

(a)

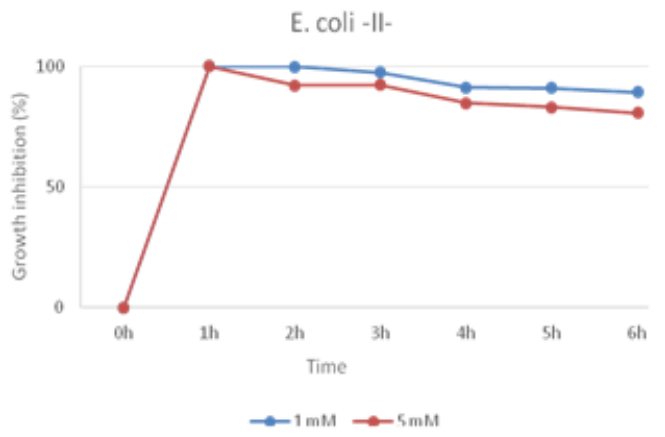

(b)

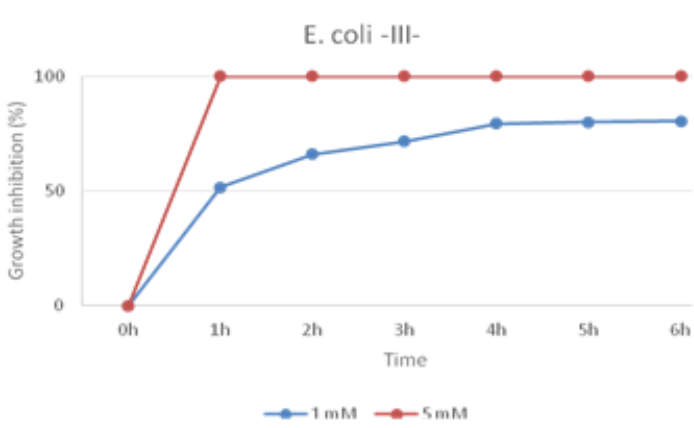

(c)

E. coll-IV-

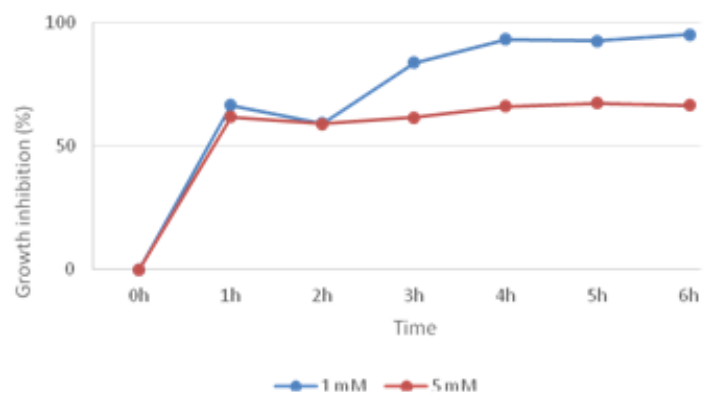

(d)

Fig. 7. Variation of growth inhibition (\%) over time for E. coli in presence of various concentrations of compounds ( $1 \mathrm{mM}$ and 5mM): (a) complex (1); b) complex (2); c) complex (3); d) chlorhexidine diacetate.

C. freundiigrowth inhibition revealed almost the same profile for all the three complexes due to their toxic effects, the $E$. coligrowth performance in the presence of complex (2) showed a great strive to survive capacity of bacterial population.

Although, chronic toxicity tests using invertebrates and vertebrates' organisms were used to assess the environmental pressures $[39,40]$, the microbial toxicity evaluation biotests were more and more preferred due to their rapidity and efficiency. 


\section{Conclusions}

We have prepared three new complex compounds derived from samarium(III) nitrate and chlorhexidine diacetate and o-phenanthroline as ligands, in 1:1 and 2:1 metal:chlorhexidine molar ratio. The complex corresponding to 2:1 samarium:chlorhexidine molar ratio, $\left[\mathrm{Sm}_{2}(\mathrm{CHX})(\mathrm{o} \text {-phen })_{2}\left(\mathrm{NO}_{3}\right)_{4}\right] \times\left(\mathrm{NO}_{3}\right)_{2}$, exhibited strong luminescent emission in solid state, characteristic of samarium(III) ion.

These complexes showed a strong antibacterial activity against $C$. freundiiand $E$. coli, being very effective in reducing the bacterial growth rate.

\section{References}

1. BYGBJ ERG, I.C., Eur. J . Clin. Pharmacol., 28, nr. 3, 1985, p. 287

2. ANGELA, M., ORTOWINE, D., WORTH, D., WERBEL, L.M., MCCALL, J.W., J. Med. Chem., 26, nr. 9, 1983, p. 1258

3. SWEENEY, D., RAYMER, M.L., LOCKWOOD, T.D., Biochem. Pharmacol., 66, nr. 4, 2003, p. 663

4. PATRON, L., GIURGINCA, M., PATRINOIU, G.M., IFTIMIE, N., MEGHEA, A., Rev. Roum. Chim., 50, nr. 6, 2005, p. 457

5. RAY, P., Chem. Rev., 61, 1961, p. 313

6. SYAMAL, A., Chem. Educ., 4, 1987, p. 33

7. SYAMAL, A., Chem. Educ., 5, 1988, p. 26

8. WOO, J.C.Y., YUEN, V.G., THOMPSON, K.H., MCNEILL, J.H., ORVIG, C., J. Inorg. Biochem., 76, nr. 4-6, 1999, p. 251

9. VIOSSAT, B., DUNG, N.H., LABOUZE, X., MORGANT, G., LANCELOT, J.C., PERRINE, D., ROBBA, M., J. Inorg. Biochem., 65, nr. 3, 1997, p. 163

10. JEANSONNE, M.J., WHITE, R.R., J. Endod., 20, 1994, p. 276

11. KUDIYIRICKAL, M.C., IVANCAKOVA, R., Acta Med., 51, nr. 1, 2008, p. 3

12. McDONNELL, G., RUSSELL, A.D., Clin. Microbiol. Rev., 12, nr. 1, 1999, p. 147

13. MOERMANN, J.E., MUEHLEMANN, H.R., J. Dent. Res., 62, nr. 2, 1983, p. 135

14. GIERTSEN, E., SCHEIE, A.A., ROLLA, G., Scand. J. Dent. Res., 96, nr. 6, 1988, p. 541

15. CHIKTE, U.M., POCHEE, E., RUDOLPH, M.J., REINACH, S.G., J. Clin. Periodont., 18, 1991, p. 281

16. GIERTSEN, E., SCHEIE, A.A., Eur. J. Oral Sci., 103, nr. 5, 1995, p. 306 17. CALINESCU, M., NEGREANU-PIRJ OL, T., GEORGESCU, R., CALINESCU, O., Cent. Eur. J. Chem., 8, nr. 3, 2010, p. 543
18. CALINESCU, M., NEGREANU-PIRJ OL, T., CALINESCU, O., GEORGESCU, R., Rev. Chim.(Bucharest), 63, no. 7, 2012, p. 682

19. BADEA, M., OLAR, R., ILIS, M., GEORGESCU, R., CALINESCU, M., J. Therm. Anal. Calorim., 111, nr. 3, 2013, p. 1763

20. NEGREANU-PIRJOL, T., CÃLINESCU, M., NEGREANU-PÎRJOL, B., DUMITRU, F., SIRBU, R., LILIOS, G., GORUN, E., GURAN, C., Archives of the Balkan Medical Union, 46, nr. 2, 2011, p. 142

21. KRTISHANAN MARGE, K.S., Main Group Chem., 7, nr. 1, 2008, p. 15 22. DOLATABADI, J.E.N., MOKHTARZADEH, A., GHAREGHORAN, S.M., DEHGHAN, G., Adv. Pharm. Bull., 4, nr. 2, 2014, p. 101

23. THAKUR, S.V., FAROOQUI, M., NAIKWADE, S.D., J. Adv. Sci. Res., 4, nr. 1, 2013, p. 31

24. SINGH, S., MALHOTRA, R., DHINDSA, K.S., Proc. Nat. Acad. Sci. India, 68(A), 1998, p. 217

25. BHATARAHAM, P.V., PATEL, D.S., IQBAL, P., J. Med. Chem, 48, nr. 24, 2005, p. 7615

26. BABYKUTTY, P.V. et al., J. Inorg. Nucl. Chem., 36, 1974, p. 3685

27. NAKAMOTO, K., Infrared and Raman Spectra of Inorganic and Coordination Compounds, 4th ed., Wiley, New York, 1986, p. 254

28. ZHU, M., LU, L., YANG, P., JIN, X., Acta Cryst., E 58, 2002, p. 217

29. ZHU, M., LU, L., YANG, P., JIN, X., Acta Cryst., E 58, 2002, p. 272

30. HUBBERSTEY, P., SUKSANGPANYA, U., Struct. Bond., 111, 2004, 33

31. HONG, J.-H., MIN, J., GUO, G.-H., ZHANG, K.-L., J. Therm. Anal.

Cal., 86, nr. 2, 2006, p. 347

32. ZHENG, Y., FU, L., ZHOU, Y., YU, J., YU, Y., WANG, S., ZHANG, H., J. Mater. Chem., 12, 2002, p. 919

33. HAVANUR, V.C., BADIGER, D.S., LIGADE, S.G., GUDASI, K.B., Der Pharma Chem., 3, nr. 2, 2011, p. 292

34. RUDRAMADEVI, B.H., BUDDHUDU, S., Indian J. Pure Appl. Phys., 46, 2008, p. 825

35. AGARWAL, R.K., PRASAD, S., GOEL, N., Turk. J. Chem., 28, 2004, p. 405

36. WANG, S., ZHU, Y., CUI, Y., WANG, L., LUO, Q., J. Chem. Soc. Dalton Trans., 1994, p. 2523

37. XU, C., Monatsh. Chem., 141, nr. 6, 2010, p. 631

38. NITA-LAZAR, M., GALAON, T., BANCIU, A., PAUN, I., STOICA, C., LUCACIU, I., J. Environ. Prot. Ecol., 17, nr. 1, 2016, p. 237

39. STOICA, C., GHEORGHE, S., PETRE, J., LUCACIU, I., NITA-LAZAR, M., Environ. Eng. Manag. J., 13, nr. 9, 2014, p. 2243

40. STOICA, C., GHEORGHE, S., LUCACIU, I., STANESCU, E., PAUN, I., NICULESCU, D., Soil Sediment Contam., 23, nr. 7, 2014, p. 763

Manuscript received: 2.08 .2017 